\title{
低熱ポルトランドセメントとシリカフュームを併用した結合材モルタルの 圧縮強度と内部組織に関する研究

\author{
STUDY ON COMPRESSIVE STRENGTH AND INTERNAL ORGANIZATION WITH \\ BINDER USING LOW-HEAT PORTLAND CEMENT AND SILICA FUME
}

\author{
河上浩司*，西本好克**，栘田佳寛*** \\ Hiroshi KAWAKAMI, Yoshikatsu NISHIMOTO and Yoshihiro MASUDA
}

\begin{abstract}
The compressive strength and internal organization of the heat curing test piece and $20^{\circ} \mathrm{C}$ seal curing test piece that made with the high strength mortar using the low heat portland cement and silica fume were confirmed.

As a result, the compressive strength of the heat curing test piece at three days is almost equal to that of the $20^{\circ} \mathrm{C}$ seal curing at 91 days.

As a result of an internal analysis, the pore size distribution curve and the amount of the calcium hydroxide of the heat curing test piece at three days was almost equal to that of $20^{\circ} \mathrm{C}$ seal curing at 91 days.
\end{abstract}

Keywords : High-strength mortar, Silica fume, Strength development, Temperature career, Microstructure 高強度モルタル, シリカフューム, 強度発現, 温度履歴, 微細構造

1.はじめに

近年, 圧縮強度が $150 \mathrm{~N} / \mathrm{mm}^{2}$ におよぶ高強度コンクリートの強度 発現に関する研究が盛んに行われている。それらの中で, 低熱ポル トランドセメントとシリカフュームを結合材とした水結合材比 $20 \%$ 以下の高強度コンクリートにおいて，最高温度が $60^{\circ} \mathrm{C}$ 程度まで上 昇する初期高温履歴を受けた供試体や構造体のコンクリート 強度は，若材龄から材齢 91 日程度までにわたり，標準養生供 試体や $20^{\circ} \mathrm{C}$ 封かん養生供試体より高強度となりうることが報 告されている1),2),3),4)。しかしながら，これらの多くは確認され た温度履歴や強度発現の報告にとどまっており, コンクリー トの内部組織等を確認することで, 高強度化に対して何らか の理由付けを行っている報告 5),6),7) はまだ少ない状況にある。

本研究は, 2 種類の結合材を用いて高強度モルタルを練り 混ぜ, 主に $20^{\circ} \mathrm{C}$ 封かん盖生供試体と初期高温履歴を受けた供 試体を対象に強度発現の確認とモルタルのマトリクス部分の 分析を行い, 初期高温履歴によって高強度化する現象につい て, 生成物や微細構造の観点から㭘討を行ったものである。

\section{2. 実験}

本実験では供試体をモルタルで作製したが, その理由は以下に記 すとおりである。コンクリートは本来複合材料であるが，本 実験ではマトリクス部分の分析を行うため混合する材料種類
は少ない方がよく，セメントペーストを用いるのが最良と考 えられた。しかし，セメントペーストでは骨材との界面が無 いため, 供試体の破壊性状がコンクリートと大きく異なると 考えられ，ペースト強度とコンクリート強度とは必ずしも対 応しなくなる可能性がある。以上の理由から，本実験はモル タルによって試験を行うこととし, 供試体は直径 $50 \mathrm{~mm}$, 高さ $100 \mathrm{~mm}$ の円柱供試体とした。

\section{1 要因と水準}

本実験における要因とその水準を表一 1 に示す。結合材種類は, 低熱ポルトランドセメント単独（記号 : L) と, 低熱ポルトランド セメントとシリカフュームを併用したもの（LSF）の 2 種類と した。水結合材比は, 低熱ポルトランドセメント単独の場合 は 3 水準, シリカフュームを併用する場合は 5 水準とした。 供試体の養生方法は標準盖生, $20{ }^{\circ} \mathrm{C}$ 封かん養生そして最高温 度を $60^{\circ} \mathrm{C}$ とる加熱養生の 3 通りとした。内部組織や構造の 分析は一部の調合に対して行い, その内容は 4 項目である。

\section{2 温度履歴}

加熱養生として設定した温度履歴を図ー 1 に示す。温度履歴は, 恒温恒湿槽を使用して与え， 4 時間の前養生の後に設定した 最高温度である $60^{\circ} \mathrm{C}$ には 18 時間後に到達するように約 $3{ }^{\circ} \mathrm{C} / \mathrm{h}$ で上昇させた。材㱓 70 時間後に恒温槽から取り出し, $20^{\circ} \mathrm{C}$ の 盖生室内に用意した簡易断熱箱（厚さ $100 \mathrm{~mm}$ の発泡スチロー

Sumitomo Mitsui Construction, Co., Ltd., M. Eng.

Sumitomo Mitsui Construction, Co., Ltd.

*三井住友建設技術研究所 T.修

** 三井住友建設技術研究所

*** 学都宮大学工学部建設学科 教授・工博
Prof., Dept. of Architecture and Civil Eng., Faculty of Eng., Utsunomiya Univ., Dr. Eng. 


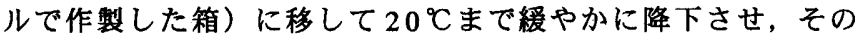
後は $20^{\circ} \mathrm{C}$ 一定で所定材龄まで存置した。温度履歴は, 熱電対 を理め込んだダミー供試体を作製して測定を行った。

\section{3 使用材料}

使用材料を表－ 2 に示す。使用する細骨材は, 吸水率の低さや化 学成分を含む品質の安定性という点から, 充分な強度が得られるこ とを予備試験により確認したうえで珪砂を選出し, 粒度の異なる 3 種類を混合して粒度分布を調整し実験に使用した。化学混和剤は, シリカフュームを混入しない場合は高性能 $\mathrm{AE}$ 減水剂を使用し，混 入する場合は超高強度コンクリート用の高性能減水郕を使用した。

\section{4 調合}

モルタルの調合を表 -3 に示す。調合は，使用材料の単位量とと もに全結合材質量を 1.0 としたときの質量比を併せて示している。 モルタルの調合は，それぞれの水結合材比に対応する一般的なコン クリートの調合から粗骨材を抜き出した值を考慮して決定した。

\section{5 練混ぜと供試体製作}

モルタルの練混ぜは，容量 $50 \mathrm{~L}$ の強制パン型ミキサを使用 して練り混ぜた。練混ぜ順序は，水以外の材料を投入して空 練りを 15 秒行い, 水結合材比が $25 \%$ 以上の調合は水と混和剤 を一括投入して $120 \sim 300$ 秒間練り混ぜた。水結合材比が $20 \%$ 以下の調合は水と混和剤を分割投入とし，水を投入して 60 秒 後に混和郕を投入して 300〜540 秒間練り混ぜた。

水結合材比の小さいモルタルでは，巻き込みエアが多かっ たが粘性が極端に高く，多少の振動を加えても分離の可能性 は無いと判断されたので，モルタルの入った練り 盤ごとテーブルバイブレーターで振動させ，巻き 込みエアを排除した後に供試体の作製を行った。

\section{6 分析内容}

内部組織の分析 ${ }^{8)}$ はL30 と LSF16 の一部に対して 実施した。今回実施した分析の項目は，量含水 率, 結合水量, 水酸化カルシウム量そして細孔径 分布である。分析用の供試体は専用とし，圧綟試 験供試体と同時に採取し同一の養生を行った。

\section{(1) 前処理}

分析を行うにあたり, 前処理として試料モルタルをジョー クラッシャーで粗粉砕し $5.0 \mathrm{~mm}$ ふるいを全量通過させた。こ こから $2.5 \mathrm{~mm}$ 以上の大きさの粒を $20 \mathrm{~g}$ 程度採取し, 細孔径分 布測定に使用した。残った試料を使用して質量含水率, 結合 水量及び水酸化カルシウム量の測定を行った。

\section{(2) 犋量含水率}

質量含水率の算出は, 圧樎試験終了後の供試体片を乾燥炉にて $105^{\circ} \mathrm{C}$ で恒量になるまで乾燥させ, 乾燥前後の質量差から算出 する方法と，分析用のモルタル供試体を破砕した破砕片を $20 \mathrm{~g}$ 程度を分取し $105^{\circ} \mathrm{C}$ で 3 時間乾燥させ, 乾煤前後の質量変化か ら算出する方法の 2 通りで行った。

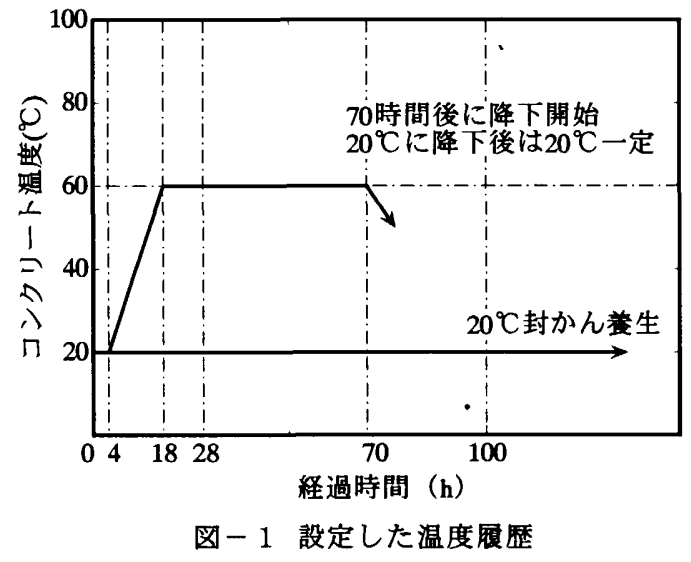

表 -1 要因と水準

\begin{tabular}{|c|c|}
\hline 要因 & 永淮 \\
\hline $\begin{array}{c}\text { 結合材種類と } \\
\text { 水結合材比 }\end{array}$ & $\begin{array}{l}\text { 低熱ポルトランドセメント (L) : } 36.7,28.1,25.0 \% \\
\text { 低熱ポルトラシドセメント+シシリフューム (LSF) } \\
: 30.0,25.0,20.0,16.7,14.3 \% \\
\end{array}$ \\
\hline $\begin{array}{l}\text { 美生と } \\
\text { 試験材齢 }\end{array}$ & 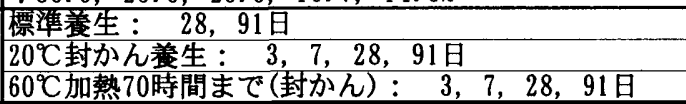 \\
\hline 内部組織分析項目 & $\begin{array}{l}\text { 目由水量(質量含水率) } \\
\text { 結合水量 } \\
\text { 水酸化力ルシウム量 } \\
\text { 細孔徍分布 }\end{array}$ \\
\hline
\end{tabular}

表 -2 使用材料

\begin{tabular}{|c|c|c|c|c|}
\hline 種類 & 名称 & \multicolumn{3}{|c|}{ 諸物性 } \\
\hline セメント & 低熱ポルトランドセメント & 密度 $3.24 \mathrm{~g} / \mathrm{cm}^{3}$ & 比表面積 $3280 \mathrm{~cm}^{2} / \mathrm{g} \quad \mathrm{C}_{2} \mathrm{~S} 56 \%$ & $\mathrm{~L}$ \\
\hline 混和材 & シリカフューム & $2.2 \mathrm{~g} / \mathrm{cm}^{3}$ & 比表面積 $22.0 \mathrm{~m}^{2} / \mathrm{g} \quad \mathrm{SiO}_{2} 97 \%$ & SF \\
\hline \multirow{3}{*}{ 紐骨材 } & 珪砂 3 号（八草産） & 真密度 $2.66 \mathrm{~g} / \mathrm{cm}^{3}$ & $\begin{array}{lll}\mathrm{SiO}_{2} & 99.6 \% & \text { Ig. loss } 0.2 \%\end{array}$ & S1 \\
\hline & 珪砂 4号（八草産） & 真密度 $2.66 \mathrm{~g} / \mathrm{cm}^{3}$ & $\mathrm{SiO}_{2} \quad 98.2 \%$ Ig. loss $0.2 \%$ & S2 \\
\hline & 珪砂 7 号 (陣屋産) & 真密度 $2.65 \mathrm{~g} / \mathrm{cm}^{3}$ & $\mathrm{Si}_{2} \quad 91.7 \%$ & S3 \\
\hline \multirow{2}{*}{ 混和剤 } & 高性能AE減水冏 & ポリカルボン酸系 & & SP1 \\
\hline & 超高強度コンクリート用高性能減水周 & ポリカルボン酸系 & & SP2 \\
\hline
\end{tabular}

表一 3 モルタル調合

\begin{tabular}{|c|c|c|c|c|c|c|c|c|c|c|}
\hline \multirow{2}{*}{ 記号 } & \multirow{2}{*}{ W/B } & \multicolumn{4}{|c|}{ 単位量 $\left(\mathrm{kg} / \mathrm{m}^{3}\right)$} & SP & \multicolumn{4}{|c|}{ 単位量（結合材量に対する比） } \\
\hline & & Tw & $\mathrm{c}$ & $\mathrm{SF}$ & $\bar{S}$ & $\mathrm{~B} \times(\%)$ & T & $\mathrm{c}$ & $\mathrm{SF}$ & $\mathrm{S}$ \\
\hline LSF30 & $30.0 \%$ & 224 & 673 & 75 & 1348 & 1.4 & 0.300 & 0.9 & 0.1 & 1.80 \\
\hline LSF 25 & $25.0 \%$ & 226 & 812 & 90 & 1231 & 1.6 & 0.250 & 0.9 & 0.1 & 1.36 \\
\hline LSF 20 & $20.0 \%$ & 226 & 1016 & 113 & 1044 & 1.8 & 0.200 & 0.9 & 0.1 & 0.93 \\
\hline LSF 16 & $16.7 \%$ & 224 & 1208 & 134 & 849 & 2.0 & 0.167 & 0.9 & 0.1 & 0.63 \\
\hline LSF 14 & $14.3 \%$ & 223 & 1405 & 156 & 660 & 2.2 & 0.143 & 0.9 & 0.1 & 0.42 \\
\hline L40 & $36.7 \%$ & 222 & 606 & 0 & 1417 & 0.9 & 0.367 & 1.0 & 0.0 & 2.34 \\
\hline L30 & $28.1 \%$ & 230 & 817 & 0 & 1330 & 1.1 & 0.281 & 1.0 & 0.0 & 1.63 \\
\hline L25 & $25.0 \%$ & 239 & 954 & 0 & 1168 & 1.2 & 0.250 & 1.0 & 0.0 & 1.22 \\
\hline
\end{tabular}




\section{(3) 結合水量}

結合水量の測定は，アセトンに 1 時間浸せきして水和を停 止させた後に $105{ }^{\circ} \mathrm{C}$ で 3 時間乾燥させた試料を用いた。なお, 結合水量は以下の手法により算定を行った。

(1)試料の $600{ }^{\circ} \mathrm{C}$ 強熱減量を日本コンクリート工学協会「コン

クリートの試験・分析マニュアル」8)に準拠して測定する。

(2)使用材料もそれぞれの $600^{\circ} \mathrm{C}$ 強熱減量を測定する。

(3)各材料の強熱減量と試料中での各材料の混合割合から, 各材料に 起因する強熱減量を算出する。(1) 式により各材料の強熱減量を試 料の強熱減量から差し引き, 残りを結合水量とする。

(4)練混ぜ時の調合及び含水量から，単位結合材量に対する結 合水の割合（結合水結合材比）を(2）式を用いて算出する。

WT $=\mathrm{L} \times(1-\mathrm{DH} / 100)$

$-(\mathrm{CL} \times \mathrm{CM}+\mathrm{SL} \times \mathrm{SM}+\mathrm{SFL} \times \mathrm{SFM}) / 100 \cdots(1)$

$\mathrm{WT} / \mathrm{B}=\mathrm{WT} /(\mathrm{CM}+\mathrm{SFM}) \times 100$

ここに, WT: 結合水量 $(\%)$

WT/B : 結合水結合材比 $(\%)$

$\mathrm{L}: 600^{\circ} \mathrm{C}$ 強熱隇量 $(\%)$

DH：質量含水率 $(\%)$

CL : セメントの $600^{\circ} \mathrm{C}$ 強熱減量 $(\%)$

SL : 細骨材の $600^{\circ} \mathrm{C}$ の強熱減量 $(\%)$

$\mathrm{SFL}$ : シリカフュームの $600^{\circ} \mathrm{C}$ 強熱減量 $(\%)$

$\mathrm{CM}$ : 調合によるモルタル中のセメントの質量百分率 (\%)

SM : 調合によるモルタル中の細骨材の質量百分率(\%)

SFM : 調合によるモルタル中のシリカフュームの質量百分 率 $(\%)$

\section{（4）細孔径分布}

細孔径分布の測定は, 試料をアセトンに 1 時間浸せきして水和を 停止させた後, D- 乾燥で恒量になるまで乾燥させた試料を用

\begin{tabular}{|c|c|c|c|}
\multicolumn{2}{c}{$\begin{array}{c}\text { 表 }-4 \\
\text { フレッシュ試験結果 }\end{array}$} \\
\hline & $\begin{array}{c}\text { 空気量 } \\
(\%)\end{array}$ & $\begin{array}{c}\text { 単位容積質量 } \\
\left(\mathrm{t} / \mathrm{m}^{3}\right)\end{array}$ & $\begin{array}{c}\text { モルタル温度 } \\
\left({ }^{\circ} \mathrm{C}\right)\end{array}$ \\
\hline LSF30 & 2.7 & 2.330 & 21.0 \\
\hline LSF25 & 2.0 & 2.381 & 21.0 \\
\hline LSF20 & 1.7 & 2.411 & 22.0 \\
\hline LSF16 & 2.3 & 2.439 & 23.0 \\
\hline LSF14 & 2.4 & 2.442 & 25.0 \\
\hline L40 & 5.8 & 2.258 & 19.0 \\
\hline L30 & 1.8 & 2.381 & 21.0 \\
\hline L25 & 2.8 & 2.405 & 22.0 \\
\hline
\end{tabular}

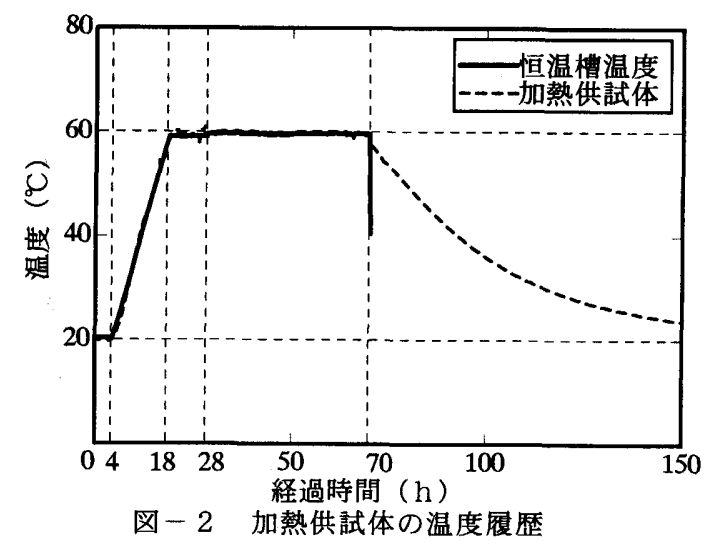

いた。細孔径分布は水銀圧入式ポロシメー夕を用い, 平均細 孔直径約 $0.003 \sim 78.1 \mu \mathrm{m}$ の範囲における圧力とそのときの压 入量 $(\mathrm{ml} / \mathrm{g})$ を計測した。

(5) 水酸化カルシウム

水酸化カルシウムの測定は, 試料 $20 \sim 30 \mathrm{mg}$ 程度を用いて 熱重量－示差熱分析（TG-DTA）を行い, $450^{\circ} \mathrm{C}$ 付近の吸熱ピー クから水酸化カルシウム生成量を測定し, 結合材量に対する 生成率を求めた。

\section{3. 実倹結果}

3.1 フレッシュモルタル

フレッシュモルタルの試験結果を表ー 4 に示す。フレッ シュ試験は，圧縮強度と微細構造への影響が特に大きいと考 えられる空気量と単位容積質量の確認を行った。L40の空気量 は他より相当大きいが, L 40 は粘性が低くテーブルバイブ レータによる巻き込みエアの除去を行わなかったことによる。 流動性については目視による確認としたが, 練混ぜたモル夕 ルはいずれも充分な流動性が確保できていた。LSF16について フロー值を確認したところ，フロー值は $250 \mathrm{~mm}$ であった。

\section{2 温度履歴}

ダミー供試体で測定した温度履歴を図ー 2 に示す。設定温 度である $60^{\circ} \mathrm{C}$ 到達した後は速やかに設定温度が維持され, 温度降下時も急激な温度低下が抑制されていることから, 図 ー 1 に示した設定温度履歴に近い温度履歴を与えることがで きた。

\section{3 圧宿強度}

圧樎試験の結果を表一 5 に, $20^{\circ} \mathrm{C}$ 封かん盖生と加熱養生を 行ったときの結合材水比と圧縮強度との関保を図一 3 に示す。 LSF の $20^{\circ}$ C封かん盖生では結合材水比 7.0 で頭打ちの傾向がみ られたので，回帰線は結合材水比 6.0 以下の範囲で算出した。

\begin{tabular}{|c|c|c|c|c|c|}
\hline & & & 强 & & \\
\hline \multirow{2}{*}{$\begin{array}{l}\text { 調合 } \\
\text { 記号 }\end{array}$} & \multirow{2}{*}{ 養生 } & \multicolumn{4}{|c|}{ 压縮強度 $\left(\mathrm{N} / \mathrm{mm}^{2}\right)$} \\
\hline & & 3日 & 7日 & 28日 & 91日 \\
\hline \multirow{3}{*}{ LSF 30} & 䐼淮養生 & - & - & 90.0 & 102 \\
\hline & $20^{\circ} \mathrm{C}$ 一定 & 44.8 & 65.6 & 92.7 & 111 \\
\hline & $60^{\circ} \mathrm{C}$ 加熱 & 97.3 & 92.9 & 99.5 & 99.9 \\
\hline \multirow{3}{*}{ LSF25 } & 標準養生 & - & - & 121 & 128 \\
\hline & $20^{\circ} \mathrm{C}$ 一定 & 65.8 & 87.5 & 123 & 125 \\
\hline & $60^{\circ} \mathrm{C}$ 加熱 & 119 & 121 & 124 & 131 \\
\hline \multirow{3}{*}{ LSF20 } & 標準養生 & - & - & 146 & 147 \\
\hline & $20^{\circ} \mathrm{C}$ 一定 & 86.0 & 110 & 133 & 153 \\
\hline & $60^{\circ} \mathrm{C}$ 加熱 & 139 & 142 & 141 & 151 \\
\hline \multirow{3}{*}{ LSF16 } & 標準養生 & - & - & 159 & 164 \\
\hline & $20^{\circ} \mathrm{C}$ 一定 & 103 & 125 & 154 & 178 \\
\hline & $60^{\circ} \mathrm{C}$ 加熱 & 163 & 157 & 156 & 172 \\
\hline \multirow{3}{*}{ LSF 14} & 標準盖生 & - & - & 160 & 182 \\
\hline & $20^{\circ} \mathrm{C}$ 一定 & 113 & 132 & 172 & 181 \\
\hline & $60^{\circ} \mathrm{C}$ 加熱 & 179 & 185 & 185 & 187 \\
\hline \multirow{3}{*}{ L40 } & 㯲準養生 & - & - & 66.2 & 96.8 \\
\hline & $20^{\circ} \mathrm{C}$ 一定 & 27.8 & 43.8 & 67.1 & 90.1 \\
\hline & $60^{\circ} \mathrm{C}$ 加熱 & 65.2 & 73.4 & 73.4 & 91.4 \\
\hline \multirow{3}{*}{ L30 } & 標準垗生 & - & - & 95.7 & 113 \\
\hline & $20^{\circ} \mathrm{C}$ 一定 & 50.8 & 67.2 & 87.0 & 109 \\
\hline & $60^{\circ} \mathrm{C}$ 加熱 & 93.7 & 96.0 & 94.2 & 112 \\
\hline \multirow{3}{*}{ L25 } & 標淮養生 & - & - & 117 & 127 \\
\hline & $20^{\circ} \mathrm{C}$ 一定 & 63.9 & 81.8 & 106 & 122 \\
\hline & $60^{\circ} \mathrm{C}$ 加熱 & 99.1 & 109 & 107 & 120 \\
\hline
\end{tabular}


$20{ }^{\circ} \mathrm{C}$ 封かん養生では, どちらの結合材とも材龄に伴い強度が 增加していくが, 加熱養生では, 材龄 3 日の時点での強度発現 が著しくなる反面その後の強度増加量は小さく, LSF で強度停 滞の傾向が顥著にみられた。

材齢 28 日と 91 日における標準養生強度と $20^{\circ} \mathrm{C}$ 封かん盖生強 度との関係を図ー 4 に示す。回帰線をみると, 低熱ポルトラン

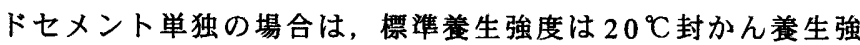
度よりも $7 \%$ 程度高くなる傾向があるが, シリカフュームを併 用した場合はどちらの養生の強度もほぼ一致した。

細孔径分布の測定を行った L30 とLSF16 の強度発現を図ー 5 に示す。L30 とLSF16 ともに，加熱養生の強度発現は若材齢で で大きく，その傾向はLSF16 でより顕著であった。また，その 後もある程度の強度增加があるため, 材㱓 91 日でもL 30 と LSF16 ともに $20^{\circ} \mathrm{C}$ 封かん盖生強度と同等となった。

\section{4 質目含水率}

質量含水率の測定結果を測定方法別に表一 6 に示す。また， それぞれの方法による測定値の比較結果を図一6に示す。圧 維試験供試体片と破砕片による測定結果はほほ $1: 1$ であり，圧 縮試験供試体片による測定結果は妥当な值であると判断され た。次に，压縮試呀供試体片で測定した量量水率の経時変化 の例を図ー7に示す。なお，材龄 0 日の量量水率とは，単位 水量と骨材中の水分量の和をフレッシュモルタル単位容積質 量で除した値で, 低熱ポルトランドセメント単独でも LSF でも $10.0 \%$ 前後であった。

全体的に，量含水率は水結合材比の低下に伴い小さくな

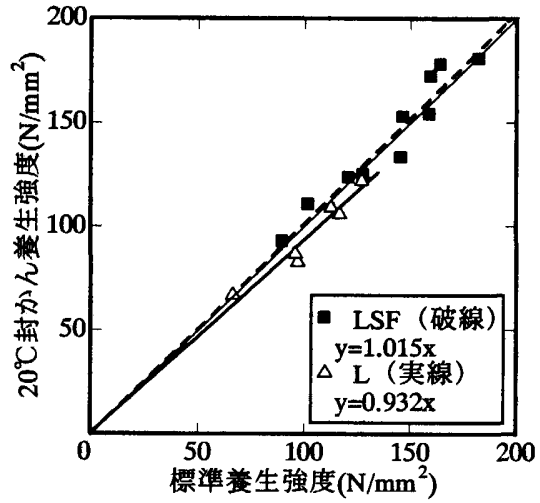

図一 4 標準盖生強度と $20^{\circ} \mathrm{C}$ 封かん盖生強度

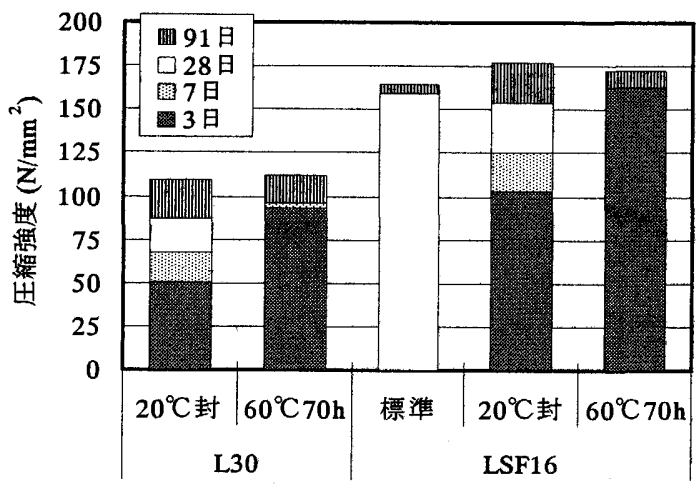

図-5 圧縮強度発現
る。養生と質量含水率の関係について検封すると，LSF30 LSF20 と低熱ポルトランドセメントでは, 標準養生の質量含 水率はその他の養生の質量含水率より高い。シリカフューム を併用したLSFでも，比較的水結合材比の大きい調合では外 部からの水が浸透していると考えられる。しかし，LSF16や LSF14 では，標準養生の質量含水率は他の養生の質量含水率 と大きな違いはなく，若材跉から組織が緻密化するために水 が浸透しにくいと考えられる。

次に，質量含水率と圧縮強度発現について検討する。低熱

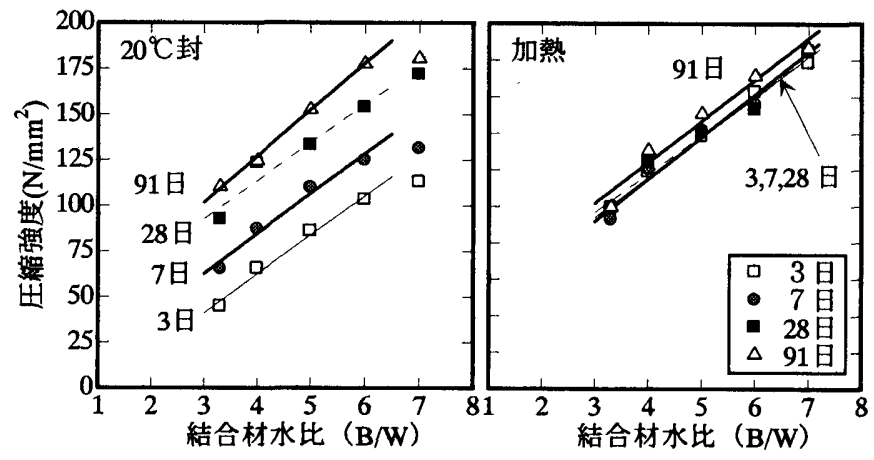

(a) L S F

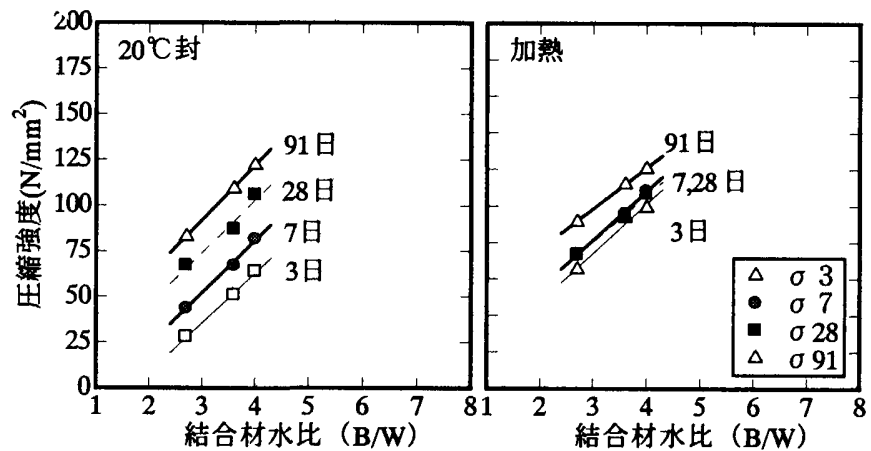

（b）低熱ポルトランドセメント

因一 3 結合材水比と压縮強度

表一 6 質量含水率

\begin{tabular}{|c|c|c|c|c|c|c|c|c|c|}
\hline \multirow{2}{*}{ 記号 } & \multirow{2}{*}{ 竟生 } & \multicolumn{4}{|c|}{ 圧縮試験片による含水率 (\%) } & \multicolumn{4}{|c|}{ 微細片による含水率 (\%) } \\
\hline & & 3日 & 7 日 & 28 日昌 & 91 日 & 3 日 & 7 日 & 28日 & 91 日 \\
\hline \multirow{3}{*}{ LSF 30} & 標準養生 & - & - & 7.93 & 7.83 & - & - & - & $\overline{-}$ \\
\hline & $20^{\circ} \mathrm{C}-$ 定 & 7.32 & 6.82 & 6.89 & 6.89 & - & 6.49 & 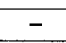 & 7.24 \\
\hline & $60^{\circ} \mathrm{C}$ 加熱 & 7.40 & 7.38 & 7.29 & 7.36 & 6.27 & 6.24 & - & 7.73 \\
\hline \multirow{3}{*}{ LSF 25} & 標準養生 & - & - & 7.39 & 7.40 & - & - & - & - \\
\hline & $20^{\circ} \mathrm{C}$ 一定 & 6.78 & 6.41 & 6.52 & 6.54 & - & 5.78 & 6.84 & 7.08 \\
\hline & $60^{\circ} \mathrm{C}$ 加熱 & 7.14 & 6.86 & 6.91 & 7.17 & 6.11 & 6.12 & - & 7.38 \\
\hline \multirow{3}{*}{ LSF 20} & 標準養生 & - & 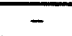 & 6.94 & 7.07 & - & - & - & - \\
\hline & $20^{\circ} \mathrm{C}$ 一定 & 6.00 & 5.91 & 6.29 & 6.20 & - & - & - & - \\
\hline & $60^{\circ} \mathrm{C}$ 加熱 & 6.32 & 6.45 & 6.31 & 6.53 & - & - & - & - \\
\hline \multirow{3}{*}{ LSF 16} & 標準盖生 & - & - & 5.73 & 6.13 & - & - & - & 7.23 \\
\hline & $20^{\circ} \mathrm{C}$ 一定 & 5.74 & 5.52 & 5.39 & 5.55 & - & 5.51 & 6.27 & 6.47 \\
\hline & $60^{\circ} \mathrm{C}$ 加熱 & 5.30 & 5.62 & 5.57 & 5.84 & 5.39 & 5.07 & - & 6.58 \\
\hline \multirow{3}{*}{ LSF 14} & 標準養生 & - & 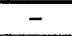 & 4.65 & 5.51 & 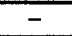 & - & $=$ & - \\
\hline & $20^{\circ} \mathrm{C}$ - 定 & 5.15 & 5.51 & 5.22 & 5.46 & - & - & - & - \\
\hline & $60^{\circ} \mathrm{C}$ 加熱 & 4.86 & 4.90 & 4.75 & 4.88 & - & $\begin{array}{ll}- \\
-\end{array}$ & - & - \\
\hline \multirow{3}{*}{ L40 } & 標陮養生 & - & - & 7.04 & 6.95 & - & - & - & - \\
\hline & $20^{\circ} \mathrm{C}$ - 定 & 6.90 & 6.66 & 6.34 & 5.99 & - & - & - & - \\
\hline & $60^{\circ} \mathrm{C}$ 加熱 & 5.92 & 5.96 & 5.80 & 5.76 & $=$ & E & - & - \\
\hline \multirow{3}{*}{$\mathrm{L} 30$} & 標準盖生 & - & - & 6.67 & 6.53 & $=$ & - & - & - \\
\hline & $20^{\circ} \mathrm{C}$ 一定 & 6.27 & 6.17 & 5.80 & 5.55 & $\begin{array}{lll}- & \\
\end{array}$ & 6.45 & 5.86 & 5.95 \\
\hline & $60^{\circ} \mathrm{C}$ 加熱 & 5.64 & 5.53 & 5.64 & 5.32 & 5.47 & 5.79 & - & 5.85 \\
\hline \multirow{3}{*}{ L25 } & 標準養生 & - & - & $6 . ?$ & 6.55 & - & - & - & - \\
\hline & $20^{\circ} \mathrm{C}-$ 定 & 6.48 & 6.11 & 6.00 & 5.74 & 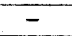 & 6.61 & - & 6.07 \\
\hline & $60^{\circ} \mathrm{C}$ 加熱 & 5.77 & 5.58 & 5.70 & 5.73 & 5.78 & 5.75 & - & 5.92 \\
\hline
\end{tabular}


ポルトランドセメントでは, $20^{\circ} \mathrm{C}$ 封かん養生の質量含水率は 材齢 3 日の時点では加熱供試体の質量含水率より相当大きい が，材齢 28 日や91日になると加熱供試体に近づいた。自由水 を緩やかに消費しながら水和が進行して，圧縮強度が加熱供 試体に追いついていったと推察される。

一方，LSFでは，標準盖生と $20^{\circ}$ C封かん荃生とで質量含水率 の差の有無に保わらず，圧縮強度が等しくなる傾向がある。 セメント単独の場合に比べ, シリカフュームを混入すると極 端に緻密化し水の浸透が妨げられるだけでなく，末水和セメ ントや末反応シリカフュームと自由水の接点がなくなってい くことなどが原因として考えられる。また，LSFでは，加熱供 試体の質量含水率は $20^{\circ} \mathrm{C}$ 封かん養生より高いことから水の消 費が少ないと推測されるにも係わらず，より高い強度が発現 している場合がある。

\section{5 結合水皇}

試料を $600^{\circ} \mathrm{C} て ゙$ 加熱したときの強熱減量から算出した結合水 量を，単位結合材量で除した結合水結合材比を表一 7 に示す。 結合水結合材比は, 調合上の水結合材比が低下すると若干低 下する。また，結合水結合材比と材齢との関倸をみると，低 熱ポルトランドセメントでは，材龄に伴い結合水結合材比が 增加していく傾向がある。一方，LSFでは材龄と共に結合水量 が単純に増加するという結果は得られず，兵量含水率の結果 と同様の結果となった。シリカフュームを混入したときに， 結合水量の增加と圧縮強度の增加の対応がとれない原因とし て, シリカフュームのポソラン反応は（3）式に示すように,

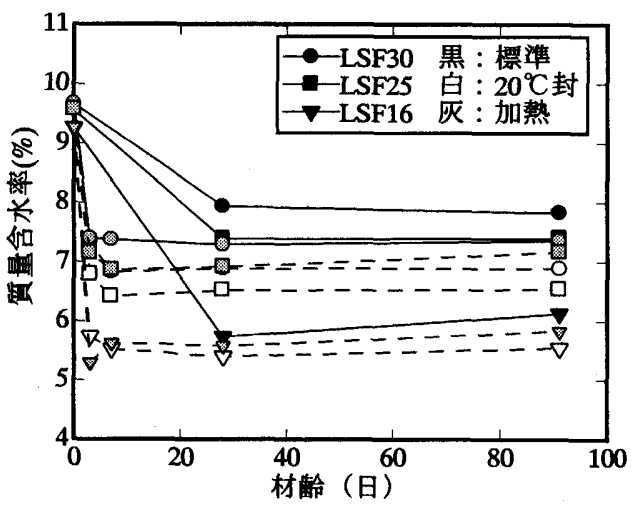

(a) L S F

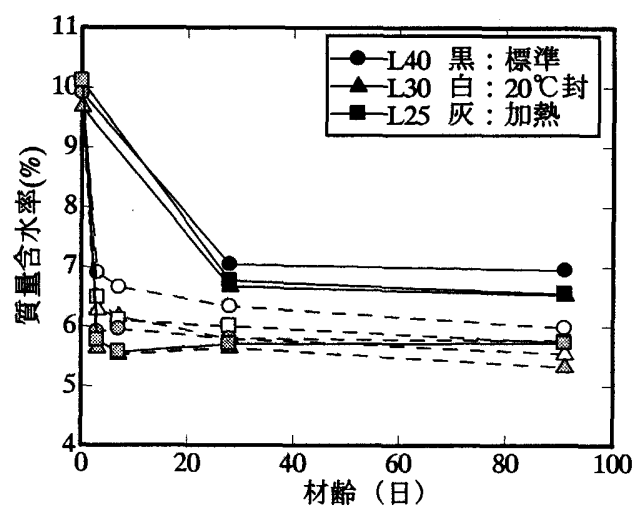

（b）低熱ポルトランドセメント 図-7 質量含水率変化
ポソラン + $\mathrm{CH}+\mathrm{H} \rightarrow \mathrm{C}-\mathrm{S}-\mathrm{H}$

ここに, $\mathrm{CH}:$ 水酸化カルシウム

$$
\begin{aligned}
& \mathrm{H}: \text { 水 } \\
& \mathrm{C}-\mathrm{S}-\mathrm{H}: \text { : カルシムシリケート }
\end{aligned}
$$

水酸化カルシウム中に存在する水分（OH）も消費して反応が 進むため，水の消費が少ないことが考えられる。

\section{6 水酸化カルシウム至}

セメントの水和反応に伴い水酸化カルシウムは生成され, シリカフュームのポソラン反応に伴い水酸化カルシウムは消 費される。すなわち, 水酸化カルシウム量の変化は, セメン 卜の水和反応の進行程度やシリカフュームのポソラン反応の 進行程度を測る目安の一つになると考えられる。

単位結合材量に対する水酸化カルシウム量の測定結果を,

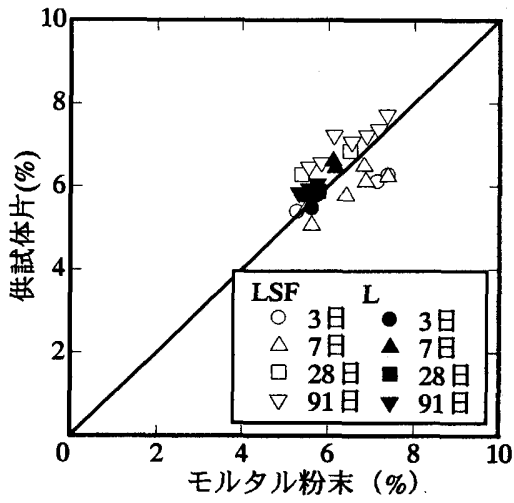

図一 6 測定法による差異

\begin{tabular}{|c|c|c|c|c|c|}
\hline \multirow{2}{*}{ 記号 } & \multirow{2}{*}{ 養生 } & \multicolumn{4}{|c|}{ 結合水結合材比 (\%) } \\
\hline & & 3日 & 7日 & 28日 & 91日 \\
\hline \multirow{3}{*}{ LSF 30} & 標準養生 & - & & 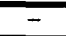 & \\
\hline & $20^{\circ} \mathrm{C}$ 一定 & - & 6.34 & - & 7.23 \\
\hline & $60^{\circ} \mathrm{C}$ 加熱 & 6.44 & 6.04 & - & 5.87 \\
\hline \multirow{3}{*}{ LSF 25} & 標淮養生 & - & - & - & \\
\hline & $20^{\circ} \mathrm{C}$ - 定 & - & 5.86 & 6.98 & 6.69 \\
\hline & $60^{\circ} \mathrm{C}$ 加熱 & 6.16 & 6.21 & - & 5.6 \\
\hline \multirow{3}{*}{ LSF 16} & 標淮養生 & - & - & - & 4.95 \\
\hline & $20^{\circ} \mathrm{C}$ - 定 & - & 4.95 & 5.08 & 4.64 \\
\hline & $60^{\circ} \mathrm{C}$ 加熱 & 5.17 & 5.17 & - & 4.52 \\
\hline \multirow{3}{*}{ L30 } & 標準養生 & - & $-\pi$ & - & - \\
\hline & $20^{\circ} \mathrm{C}$ 一定 & - & 7.18 & 9.45 & 9.38 \\
\hline & $60^{\circ} \mathrm{C}$ 加熱 & 9.24 & 9.32 & - & 10.2 \\
\hline \multirow{3}{*}{ L25 } & 標準養生 & - & - & & - \\
\hline & $20^{\circ} \mathrm{C}$ 一定 & - & 7.04 & - & 8.87 \\
\hline & $60^{\circ} \mathrm{C}$ 加熱 & 8.90 & 9.02 & - & 9.14 \\
\hline
\end{tabular}

表 -7 結合水結合材比

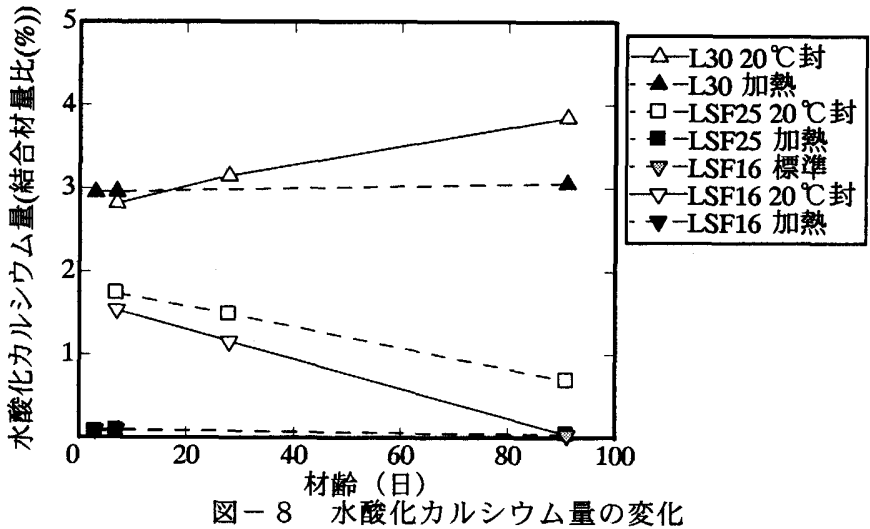


図－8に示す。L30 の水酸化カルシウム量は, $20^{\circ} \mathrm{C}$ 封かん盖生 では材齢に伴い増加し水和の進行がうかがえる。加熱養生の 水酸化カルシウム量は, 材齢 3 日では $20^{\circ} \mathrm{C}$ 封かん盖生より高 いが長期材齢ではほとんど増加しない。初期高温履歴により 初期強度が増加し，長期強度が停滞することと対応している。

LSF25 と LSF16 の水酸化カルシウム量をみると, $20^{\circ} \mathrm{C}$ 封かん 盖生では材龄 7 日以降徐々に減少し, 材龄 91 日ではLSF25 と LSF16のどちらもほぼ0\%となることから，ポゾラン反応が緩 やかに進行したと判断できる。一方，加熱養生では材秢 3 日 で 0\%となり,その後も $0 \%$ のまま変化しない。高温履歴によ りセメントだけでなくシリカフュームの反応も急激に進行し, セメントの水和によって生成した水酸化カルシウムをすぐさ ま消費したと考えられる。

\section{7 細孔径分布}

細孔径分布の測定結果を図ー9に，累積細孔量の分布を図 - 10 に示す。累積細孔量とは，その径から78.1 $\mu$ 四までの細 孔量の総和で, 例えば, 直径 $0.01 \mu \mathrm{m}$ における果積細孔量は $0.01 \sim 78.1 \mu \mathrm{m}$ の範囲の細孔量の総和である。細孔径分布をみ ると, L30では $0.015 \mu \mathrm{m}$ 近辺に分布のピークがある。材齢の 経過に伴い，練孔量のピークは若干小径側に移動するが，細 孔量自体の減少がより顕著である。圧維強度と細孔径分布を 比較すると，加熱養生の材龄 7 日と $20^{\circ} \mathrm{C}$ 封かん養生の材齢 28 日では，圧維強度が等しいだけでなく細孔量と累積細孔量の 分布も非常に類似している。同一の調合であれば压縮強度と 細孔径分布とが良い対応を示すと推察される。

LSF16では，加熱善生すると材龄 3 日の時点で細孔量のピー クは直径 $0.010 \mu \mathrm{m}$ 以下で, また累樌細孔量も非常に少ないこ
とから絰密化が進行していると考えられる。また，その後も 細孔径分布がほとんど変化しないことから, 若材齢において 非常に高い強度が得られ，長期材齢における強度増加量が小 さいことと対応していると考えられる。一方, $20^{\circ} \mathrm{C}$ 封かん養 生下の場合は, 材齢 7 日では L30 と同じ直径 $0.015 \mu \mathrm{m}$ 付近に 分布の細孔量のピークを確認できるが, 細孔量自体は L 30よ り少ない。また, 材跉 28 日では $0.015 \mu \mathrm{m}$ 付近のピークは消 失しより小さい $0.010 \mu \mathrm{m}$ 以下の細孔量が卓越し, 材齢 91 日 になると細れ径分布は加熱養生とほほ一致した。細孔量の ピークの大きな変化は, シリカフュームによる繥密化による と考えられる。細孔径分布からも, シリカフュームのポソラ ン反応は, $20{ }^{\circ} \mathrm{C}$ 環境下では材龄 7 日以降の長期に渡り進行し ていると推察された。標準養生の材龄 91 日での細孔径分布を 確認したところ, 累積細孔量の分布は $20^{\circ} \mathrm{C}$ 封かん盖生や加熱 荃生の材跲 91 日の分布に近いが $0.010 \mu \mathrm{m}$ 末満の細孔が際 だって少なく, 文献 9) に似た結果を示した。

累積細孔量と圧縮強度との関係の一例を, 回㚴線とともに 図ー 11 に示す。低熱ポルトランドセメントを単独使用した場 合とシリカフュームを併用した場合のどちらも，累積した細 孔の最小径によらず累積細孔量の增加に伴い圧縮強度は減少 する。しかし，L30 とLSF16では，累積対象とした細孔径ごと に回制線の傾きは近いが, 同一累積細孔量でも得られる強度 はLSF16 のほうが大きい。文献 10)では, 硬化体強度の決定要 因として，水和物の生成量や空箵量だけでなく，水和物の種 類や水和物自体の強度の影棘が報告されている。また, 生成 する $\mathrm{C}-\mathrm{S}-\mathrm{H}$ 水和物中の $\mathrm{CaO} / \mathrm{SiO}_{2}$ 比が小さいほど水和物の強度は 高くなること, シリカフュームのポソラン反応により水和物
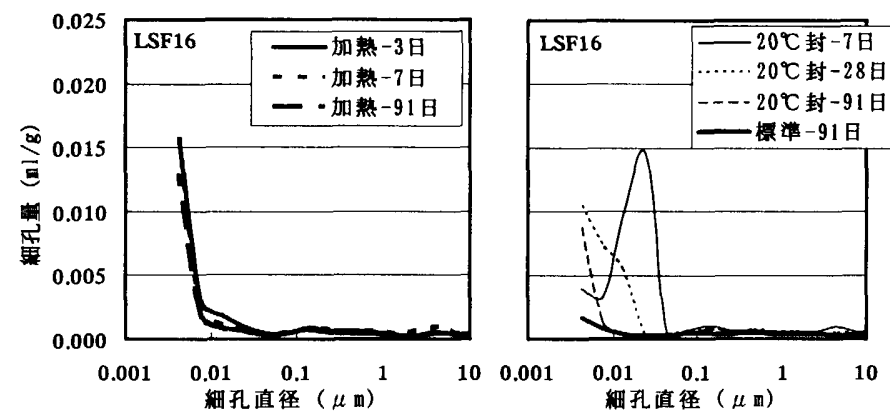

(a)LSF16
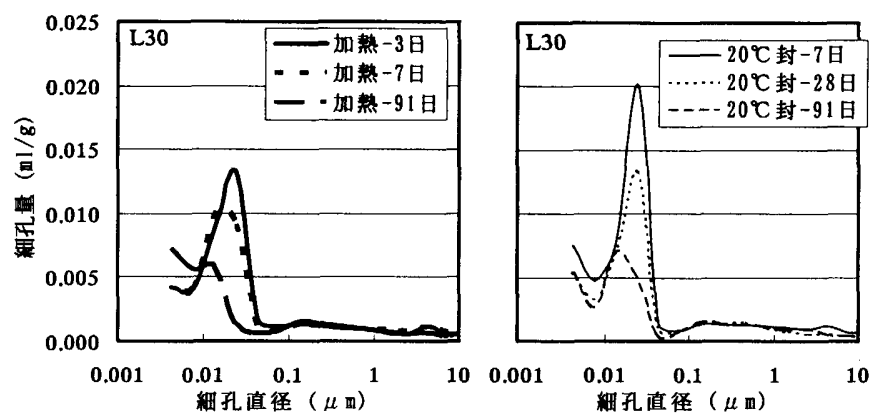

(b) L30

\section{図一9細孔径分布}
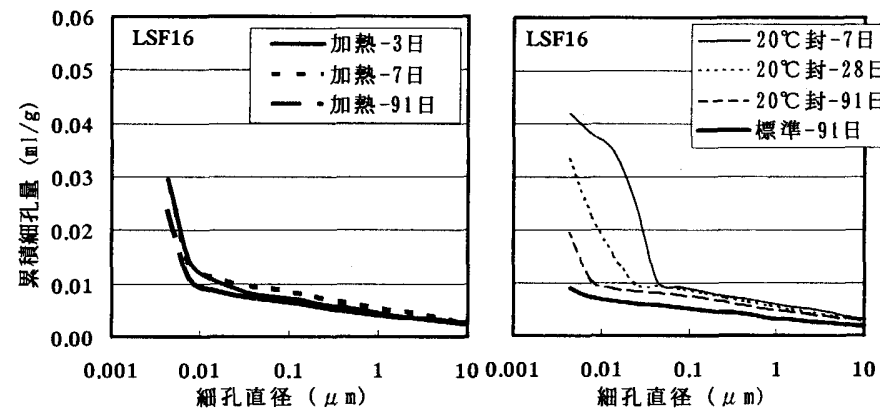

(a)LSF16
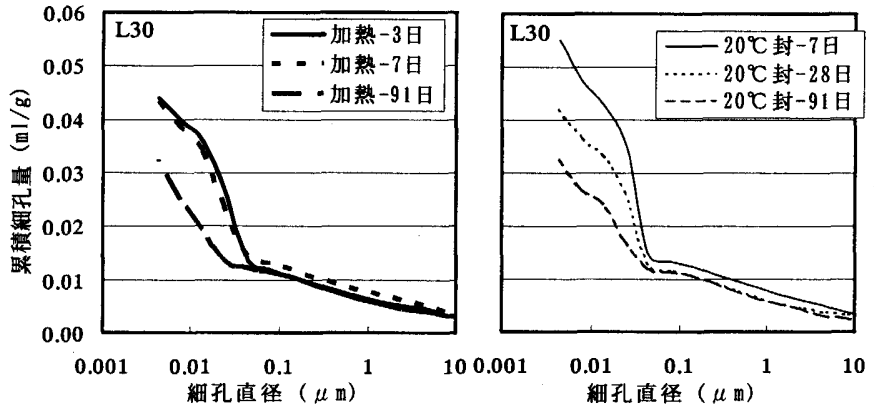

(b) $\mathrm{L} 30$

図-10 累積細孔量分布 


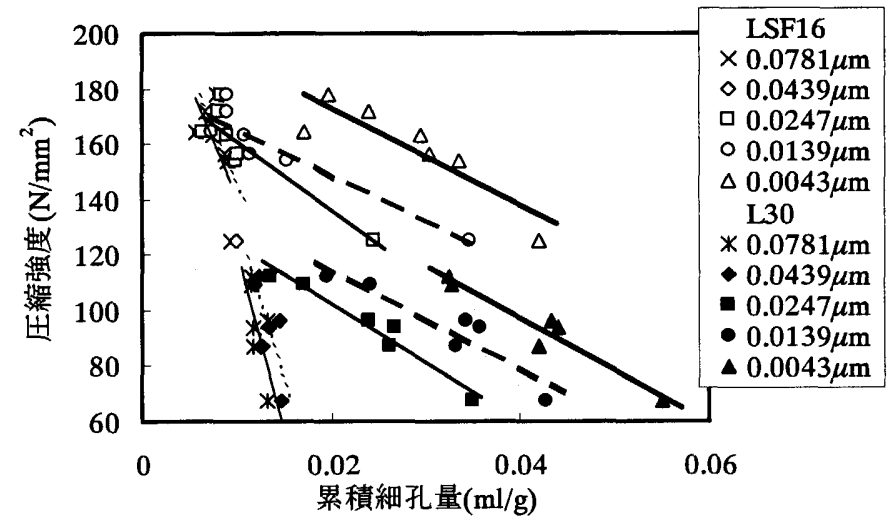

図-11累積細孔量と圧縮強度の関係の例

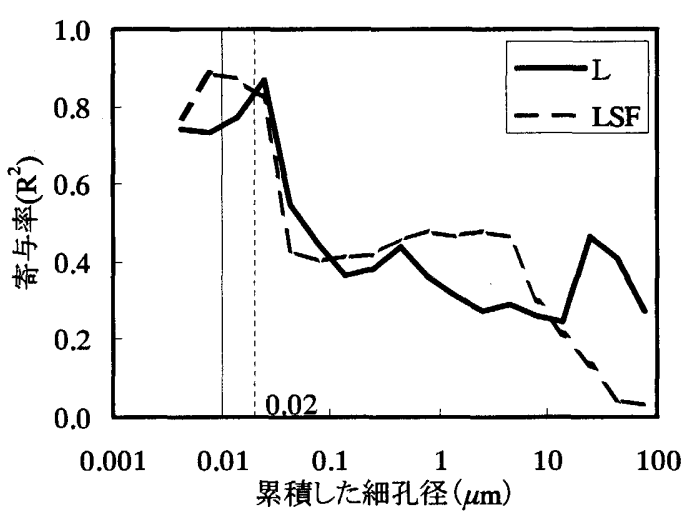

図ー12 累積した細孔径の最小值と 圧縮強度回帰式の寄与率分布

(5) 同一の累積細孔量の時は, 得られる強度はポルトランドセ メント単体の結合材よりシリカフュームを併用した結合材 の方が高い。

\section{解辞}

本研究の実施にあたり，住友大阪セメント（株）鈴木康範 氏，上原伸郎氏，（株）NMB の菅俣匠氏に貴重なアドバイス を頂きました。また,（株）中研コンサルタントの近藤英彦氏 には分析作業に関してご尽力いただきました。ここに付して 感謝の意を表します。

文献 11) では, $60 \mathrm{~N} / \mathrm{mm}^{2}$ 級までのモルタルの細孔径と圧縮強 度との対応を調べ, $0.050 \sim 2.0 \mu \mathrm{m}$ 程度の細孔量との圧縮強 度との相関が高かったと報告されているが, 今回の実験結果 からは $100 \mathrm{~N} / \mathrm{mm}^{2}$ 程度（L30）では $0.020 \mu \mathrm{m}$ 程度以上の細孔径 が圧縮強度に与える影響が大きく, それ以上の $150 \mathrm{~N} / \mathrm{m} \mathrm{m}^{2}$ 程度 （LSF16）ではさらに小さい $0.010 \mu \mathrm{m}$ 程度以上の細孔量が圧縮 強度に与える影響が大きくなると推察された。

\section{4.まとめ}

本研究において得られた知見を以下に示す。

(1) 低水結合材比の高強度モルタルを $60^{\circ} \mathrm{C}$ 程度で加熱養生した 場合，材龄 3 日ないし 7 日で標準養生や $20^{\circ} \mathrm{C}$ 封かん養生の 材齢 91 日強度相当の強度が発現する。

(2) 低熱ポルトランドセメントとシリカフュームを併用した結 合材に対し $60{ }^{\circ} \mathrm{C}$ 程度の加熱養生を行った場合, シリカフュ 一ムのポソラン反応が活性化し, 水酸化カルシウムの消費 程度は, 若材齢で梆準盖生や $20^{\circ} \mathrm{C}$ 封かん養生の材龄 91 日に 相当する。

(3) 低熱ポルトランドセメントとシリカフュームを併用した結 合材に対し $60^{\circ} \mathrm{C}$ 程度の加熱養生を行った場合, マトリクス は若材齢で $20^{\circ} \mathrm{C}$ 封かん盖生材齢 91 日と同程度の緻密度とな る。

(4) 圧縮強度 $100 \mathrm{~N} / \mathrm{mm}^{2}$ 程度のマトリクスでは, $0.020 \sim 78.1 \mu$ $\mathrm{m}$ の累積細孔量と圧縮強度の相関が高く, $150 \mathrm{~N} / \mathrm{m} \mathrm{m}^{2}$ 程度に なるとそれより小さい $0.010 \sim 78.1 \mu \mathrm{m}$ の累積細孔量と圧縮 強度の相関が高かった。

\section{考文献}

1）河上浩司, 梸田佳寛, 西本好克, 蓮尾孝一 : 結合材種類の異なる高強度 コンクリートの強度発現性状に関する研究, 日本建築学会構造系論文集 第 576 号, pp.23-29,2004.2

2) 21 世紀のコンクリート，2001 年度日本建榮学会大会（関東）材料施工 部門，パネルディスカッション資料，2001.9.24

3）土谷 正, 清水哲史, 岡沢 智: 超高強度コンクリートの強度発現性お よび耐久性に関する一考察, 日本建娼学会学術講演梗概集, A-1, pp-199$200,2001.9$

4) 日本建築学会 : 高強度コンクリート施工指針・同解説,2005.2

5) 芦俣 匠, 杉山知巳, 梅沢健一, 岡沢 智: セメントーシリカフューム 系結合材の水和反応と強度発現性の関係に関する一考察, コンクリートエ 学年次論文集,Vol.26, No.1, pp.1287-1292, 2004.7

6) 陣内 浩, 黒岩秀介, 早川光敬 : 初期に高温履歴を受ける高強度セメン 卜硬化体の強度発現性状と微細構造, 日本建築学会構造系論文集, No.542, pp.39-46,2001.4

7) Hiroshi Jinnai, Shusuke Kuroiwa, Mitsutaka Hayakawa, Yoshihiro Masuda :Strength Development and Microstructure of High Strength Cement Paste Subject to High Temperature at Early Age, 6th International Symposium on High Strength / High Performance Concrete, pp.1079-1088, 2002

8) 日本コンクリート工学協会 : コンクリートの試験・分析マニュアル, 2000.5 9) 鳥居和之, 川村満紀 : 高温履歴を受ける超高強度コンクリートの微細組 较と強度発現性，第 49 回セメント技術大会講演集, pp.520-525,1995

10) 例えば 内川 浩 : 混合セメントの水和および構造形成に及ぼす混和材 の効果, セメント・コンクリート,No.488, pp.33-48,1987.10

11）羽原俊祐 : 硬化コンクリートの組織および空隙構造と物性の関係に関す る研究, 鹿堆塾大学学位論文,1992 年度

（2005年 6 月 8 日原稿受理， 2005 年 9 月 29 日採用決定） 